\title{
Inisiasi Pembentukan Desatoleransi sebagai Wujud Pencegahan Paham Radikal Terorisme
}

\author{
Siti Azizah*, Desy Churul Aini, Dimas Zakaria \\ Ilmu Hukum, Universitas Lampung, Bandar Lampung, 35145, Lampung, Indonesia
}

\begin{abstract}
Abstrak.
Bahaya paham radikal terorisme diawali dari semakin minimnya pemahaman tentang toleransi beragama. Pemahaman bahwa agamanya paling benar dan agama lain salah adalah cikal bakal munculnya paham radikal terorisme. Kelompok radikalisme dan terorisme mengembangbiakkan ideology mereka ibarat amuba dengan cara membelah diri, strategi penyebaran sel melalui banyak tubuh yang berbeda. Jati diri kaum muda dimanfaatkan oleh kelompok radikal terorisme sebagai wadah mutasi penerus ideology radikal, sampai pelaku aksi teror. Badan Nasional Penanggulangan Terorisme (BNPT) sebagai lembaga Pemerintah non kementerian yang diamanatkan menangani terorisme, memandang penting aspek pencegahan yang bersifat lunak dalam upaya mewaspadai berkembangnya radikalisme dan terorisme yang membajak kepercayaan tertentu di masyarakat. Diyakini pendekatan lunak dalam berbagai bentuk, salah satunya melalui seni budaya, adalah metode yang efektif meningkatkan daya tangkal masyarakat, khususnya generasi muda, menolak ajaran dan ajakan kekerasan yang diinisiasi kelompok radikal terorisme.
\end{abstract}

Kata kunci.

Terorisme, Radikalisme dan Desa

\section{PENDAHULUAN}

\section{Latar Belakang}

Pengabdian kepada masyarakat ini merupakan kegiatan lanjutan dari penelitian yang sudah dilakukan pada tahun 2018 dengan tema penguatan daya tangkal masyarakat terhadap paham radikal terorisme melalui pengembangan kearifan lokal yang didanai oleh Badan Nasional Penanggulangan Terorisme (BNPT).

Sebagaimana hasil penelitian menyebutkan bahwa $50 \%$ munculnya paham radikal terorisme disebabkan karena faktor kesenjangan sosial di masyarakat baik kota maupun desa karena tidak meratanya pembangunan selain juga akibat pemahaman agama yang sempit dimasyarakat sehingga dengan mudah dipengaruhi untuk melakukan tindakan terorisme. Kemudian juga munculnya paham radikal terorisme akibat pengaruh pemberitaan asing khususnya terkait kebijakan pemerintah Amerika Serikat pada penyelesaian kasus Israel vs Palestina yang kemudian memunculkan sentimen keagamaan

\section{* Corresponding author: upik.azizah29@gmail.com}

Received 18 November 2020; Received in revised form 28 November 2020; Accepted 9 December 2020 Available online 24 December 2020

Lembaga Penelitian dan Pengabdian Kepada Masyarakat

Universitas Lampung 
di masyarakat.

Disatu sisi Lampung sebagai ujung tombak Pulau Sumatera dalam hal distribusi barang dan orang dengan Pulau Jawa sangat rentan sekali untuk dijadikan tempat pelarian dan penyebaran paham radikal terorisme. Hal ini sebagaimana hasil penelitian yang dilakukan oleh BNPT menunjukkan bahwa Lampung masuk pada peringkat ke-4 (empat) sebagai wilayah atau zona merah tempat persembunyian napi terorisme [1]

Bahkan pada tanggal 21 Oktober 2019 polisi telah menangkap 3 (tiga) terduga teroris di Lampung [2]. Sedangkan jauh sebelum itu telah terjadi peristiwa peristiwa Talang Sari pada era orde baru yang yang diidentifikasi dilakukan oleh kelompok NII. Kelompok NII di daerah ini yang diketuai oleh almarhum Warsidi, sebagian pengikut mereka masih hidup. Sebagian mereka yang masih hidup, ada juga yang kemudian melakukan perjuangan untuk mewujudkan NII dilakukan dengan aktivis PRD, aktivis kelompok NII, dan aktivis komando jihad. Sebagian mereka juga kemudian bergabung dengan kelompom radikal terorisme yang di dalamnya beranggotakan kelompok NII, sehingga kelompok NII Lampung Timur juga ada yang terlibat dalam aksi teror antara lain tokohnya bernama Moh. Fuad Mahmud alias Fuad, dengan alamat Dusun IV RT 002/RW 008 Desa Teluk Dalam, Kecamatan Mataram Baru, Kabupaten Lampung Timur. Fuad memiliki jaringan dengan kelompok NII lain di dalam dan luar Lampung terutama dengan KW 9.

Fuad juga bergabung dengan kelompok MMI di dalam dan luar Lampung, namun kelompok NII di Lampung Timur sudah lemah gerakan ke permukaan bersamaan dengan pengaruh secara umum kelompok NII di Lampung yang sebagaian mereka juga teridentifikasi sebagai kelompok mantan teroris,antara lain: Sumarzuki, Danial Harun, Murni Sulaiman, dan lainnya.

Disisi lain secara geografis, Lampung Timur bersebelahan dengan Lampung Selatan sebagai pintu masuk dan keluar dari dan ke Pulau Jawa. Hal ini akan berpengaruh juga terhadap desa dimana tempat pengabdian akan dilaksanakan yaitu Kecamatan Jatiagung desa Karang Sari yang letaknya sangat berdekatan dengan Kota Bandar Lampung namun jauh dari pusat ibu Kota Lampung Selatan yaitu Kalianda.

\section{Permasalahan Mitra}

Desa karang sari kecamatan Jati Agung merupakan desa yang posisinya dekat dengan ibu kota provinsi namun jauh dari ibu kota Kabupaten. Sehingga dalam sisi perkembangan pembangunan banyak diabaikan karena pemerintah kabupaten Lampung Selatan lebih memperhatikan wilayah diseputar Kalianda sebagai pusat pemerintahan Kabupaten Lampung Selatan. Apalagi di desa karang sari penduduknya heterogen baik secara sosial budaya maupun agama. Maka sangat rentan sekali untuk dijadikan basis pemikiran paham radikal yang mengarah pada tindakan terorisme karena jauhnya dari perhatian pemerintah kabupaten.

\section{Tujuan Kegiatan}

Tujuan kegiatan inisiasi pembentukan desa toleransi adalah menyebarkan paham dan pemikiran tentang pentingnya toleransi antar umat beragama sebagai upaya mengikis berkembangnya paham radikal terorisme di kalangan warga desa.

\section{Manfaat Kegiatan}

Adapun manfaat kegiatan ini adalah sebagai berikut:

1. Menumbuh kembangkan pemikiran toleransi antar umat beragama sebagai upaya pencegahan paham radikal terorisme;

2. Meningkatkan pemahaman kepada masyarakat desa khususnya dan umumnya semua masyarakat terkait ciri-ciri paham radikal terorisme dan cara pencegahannya. 


\section{SOLUSI DAN TARGET LUARAN}

Terorisme yang marak terjadi dengan latar belakang ideology tertentu, berawal dari intoleransi yang kemudian mengalami radikalisasi hingga berujung pada aksi bom bunuh diri, penyerangan, dan kekerasan lainnya. Permisifitas kepada intoleransi (lesser threat) membuka ruang lebar mobilisasi radikalisme gerakan ekstrem yang pada gilirannya berujung pada aksi terorisme (bigger threat). Pada prinsipnya mereka tidak bisa menerima perbedaan, merasa paling benar sendiri, serta menyalahkan semua hal dan orang lain di luar dirinya, kelompoknya, dan keyakinannya, bahkan dengan mudah mengkafirkan untuk membenarkan kesalahanpandangan mereka tentang jihad yang sarat kekerasan dalam situasi damai.

Di Indonesia, kelompok radikalisme tersebut di atas merongrong kedaulatan Negara Kesatuan Republik Indonesia berdasarkan Pancasila dengan Bhinneka Tunggal Ika terpola pada 2 (dua) tipologi gerakan. Pertama, gerakan revolusioner berciri pergerakan persuasif, melalui penguatan wacana dan jaringan, bahkan memanfaatkan instrument demokratis. Kedua, gerakan revolusioner yang memaksa dengan penggunaan kekerasan, mulai dari brainstorming radikalisme hingga aksi terorisme.

Maka hasil FGD merekomendasikan selain melawan paham radikalisme melalui penguatan paham keagamaan dan kegiatan fisik melalui densus 88 anti terorisme diperlukan juga menggunakan kearifan lokal baik berupa menggalakkan kembali budaya phi'il pesanggiri dan rembuk pekon atau kampung dalam menyelesaikan setiap permasalahan.

Oleh karena itu inisiasi pembentukan desa toleransi menjadi salah satu cara melawan paham radikal terorisme di masyarakat dengan menggalakkan kembali gotong royong, tolong menolong dan saling menghormati antar pemeluk agama.

\section{PEMBAHASAN}

\section{Penyebaran Aliran Radikalisme}

Memasuki abad ke 21, kedamaian dan ketenangan kehidupan sosial keagamaan di Indonesia terguncang dengan munculnya serentetan aksi radikal maupun terorisme yang dilakukan oleh sekelompok orang dengan mengatasnamakan Islam. Rentetan aksi radikal Terorisme dimaksud diawali dengan meledaknya sebuah bom di depan kedubes Filipina pada tanggal 1 Agustus 2000 disusul dengan ledakan yang sama di depan Kantor Kedubes Malaysia pada tanggal 27 Agustus 2000. Sebulan berikutnya, sebuah bom meledak di Gedung Bursa Effek pada tanggal 13 September 2000, yang kemudian diikuti dengan serentetan ledakan di malam Natal 24 Desember 2000.

Setahun berikutnya, tepatnya di tahun 2001, serangkaian ledakan bom kembali terjadi di tanah air ini, antara lain: di Gereja Santa Anna dan HKBP Kalimalang, Jakarta Timur, tanggal 22 Juli 2001, di Plaza Atrium Senen Jakarta tanggal 23 September 2001, di restoran KFC, Makassar tanggal 12 Oktober 2001; dan di lingkungan sekolah Australia, Jakarta, tanggal 6 November 2001.

Pada tahun 2002, serangkaian ledakan bom kembali terjadi. Ledakan pertama berasal dari granat manggis yang terjadi di kawasan Bulungan Jakarta tepat pada malam tahun baru 1 Januari 2002. Pada malam yang sama, empat ledakan bom terjadi pula di beberapa Gereja di Palu. Beberapa bulan kemudian, tepatnya pada tanggal 12 Oktober 2002, tiga ledakan hebat yang berasal dari bom rakitan mengguncang Bali dan menewaskan ratusan orang. Pada saat yang hampir bersamaan, di Manado, Sulawesi Utara dan di halaman kantor Konjen Filipina, terjadi ledakan meski tidak ada korban jiwa. Aksi radikal terorisme pada tahun ini diakhiri dengan ledakan Bom di Restoran McDonald, Makassar pada tanggal 5 Desember 2002 yang menyebabkan 3 orang tewas dan 11 luka-luka.

Tahun 2003, bom kembali meledak di lobi Wisma Bhayangkari Kompleks Mabes Polri, Jakarta, tanggal 3 Februari 2003. Di susul dengan ledakan di area publik terminal 2F, 
Bandara Soekarno-Hatta, Jakarta, tanggal 27 April 2003. Selang sebulan kemudian, tepatnya tanggal 5 Agustus 2003, Aksi bom bunuh diri menghancurkan sebagian Hotel JW Marriott Jakarta dan menyebabkan 11 orang meninggal dunia dan 152 orang lainnya mengalami luka-luka.

Tahun berikutnya, yakni tahun 2004, sejumlah bom rakitan kembali meledak, di antarannya di Palopo, 10 Januari 2004 yang menewaskan empat orang. Selain dari itu, pada tanggal 9 September 2004, Bom bunuh diri kembali terjadi di depan Kedutaan Besar Australia. 5 orang tewas dan ratusan lainnya luka-luka. Ledakan juga mengakibatkan kerusakan beberapa gedung di sekitarnya seperti Menara Plaza 89, Menara Grasia, dan Gedung BNI. Tiga bulan berikutnya ledakan bom kembali bergema di Palu, tepatnya di Gereja Immanuel, Sulawesi Tengah pada tanggal 12 Desember 2004.

Tahun 2005, dua bom rakitan kembali meledak di Ambon (tanggal 21 Maret 2005), Tentena (28 Mei 2005), Pamulang, Tanggerang (8 Juni 2005), Bom Bali II (1 Oktober 2005), dan di sebuah pasar di Palu, Sulawesi Tengah yang menewaskan 8 orang dan melukai sedikitnya 45 orang.

Tahun 2009, kembali Bom bunuh diri melanda Jakarta, tepatnya di Hotel JW Marriott dan Ritz-Carlton, tanggal 17 Juli 2009. Dua tahun berikutnya, pada tanggal 15 April 2011, ledakan bom bunuh diri terjadi di Masjid Mapolresta Cirebon saat Salat Jumat yang menewaskan pelaku dan melukai 25 orang lainnya. Seminggu setelah peristiwa itu, tanggal 22 April 2011, sebuah bom ditemukan di jalur pipa gas namun berhasil dijinakkan, dengan sasaran Gereja Christ Cathedral Serpong, Tangerang Selatan, Banten. Tanggal 25 September di tahun yang sama, terjadi lagi ledakan bom bunuh diri di GBIS Kepunton, Solo, Jawa Tengah, yang mengakibatkan satu orang pelaku bom bunuh diri tewas dan 28 lainnya terluka.

Rentetan peristiwa di atas berikut dampak yang diakibatkannya, menunjukkan bahwa aksi radikalisme dan terorisme merupakan suatu fenomena yang destruktif yang mengancam kehidupan manusia baik secara sosial, ekonomi, politik maupun keamanan. Lebih jauh lagi, aksi-aksi radikal dan terorisme yang dilakukan oleh segelintir orang yang mengatasnamakan Jihad fi sabilillah jelas telah mencoreng nama Islam dan menimbulkan kecemasan tidak saja di kalangan umat non-Muslim tetapi juga di kalangan umat Muslim itu sendiri.

Sebagian kalangan berpendapat bahwa fenomena radikalisme-terorisme yang marak di tingkat lokal maupun global hanyalah ciptaan atau rekayasa fihak tertentu untuk memberikan citra negatif kepada umat Islam. Sebagian lagi berpendapat bahwa gerakan ini murni muncul dari internal umat Islam, sebagai respon terhadap ketimpangan dan ketidakadilan politik dan ekonomi yang dilakukan oleh dunia Barat terhadap dunia Islam. Terlepas dari apa sesungguhnya yang sedang terjadi, namun faktanya aksi-aksi radikal dan teror telah mendatangkan kerugian bagi seluruh warga masyarakat baik yang secara langsung maupun yang tidak langsung menjadi korban dari aksi-aksi kebrutalan itu. Jelasnya, radikalisme dan terorisme harus mendapatkan perhatian yang sangat serius dari semua fihak, tidak saja dari aparat kemanan melainkan dari seluruh warga masyarakat.

Sementara itu, Provinsi Lampung, sebagai suatu bagian dari wilayah NKRI, dalam kenyataannya tidak dapat dipandang steril dari pengaruh-pengaruh bahaya radikalismeterorisme. Hal ini dibuktikan dengan berkali-kali ditangkapnya anggota/jaringan teroris di wilayah ini, seperti : Solihin (41) alias Abdul Latif alias Dino alias Wawan; Muhammad Ali (20) alias Andika alias Dika alias Dwi Putra Mahardika; Dedy Rofaizal (42) alias Faisal alias Jaka serta beberapa orang lainnya yang diduga terkait dengan Jaringan teroris. Meski fakta selanjutnya membuktikan bahwa tidak ada seorangpun anggota jaringan teroris yang telah tertangkap berasal dari penduduk Lampung, namun setidak-tidaknya kenyataan itu mengindikasikan bahwa Lampung telah menjadi target persembunyian atau pelarian para anggota teroris. Ini berarti bahwa kewaspadaan dari semua fihak harus selalu ditingkatkan agar Provinsi ini tidak menjadi tempat persembunyian pelaku teroris sekaligus juga untuk mencegah berkembangnya faham/gerakan radikal terorisme yang sangat berbahaya itu. 


\section{Pembentukan Desa Toleransi sebagai upaya pencegahan paham radikalisme}

Istilah "Desa" secara etimologis berasal dari kata "swadesi" bahasa sansakerta berarti wilayah, tempat atau bagian yang mandiri dan otonom [3]. Istilah desa sendiri sangat beragam di berbagai tempat di Indonesia. Desa hanya dipakai dalam masyarakat pulau Jawa, Madura dan Bali.Sedangkan masyarakat Aceh menggunakan nama Gampong atau Meunasah, masyarakat Batak menyebutnya dengan Kuta atau Huta, didaerah Minangkabau disebut dengan Nagari, Dusun atau Marga di Sumatera Selatan [4], kemudian di Lampung disebut dengan Dusun atau Tiuh. Maka dari itu ada istilah di daerah Lampung yang amat populer yaitu "mulang tiuh" atau pulang ke desa bagi orang kota yang sukses untuk membangun daerahnya atau desanya.

Kata "desa"tersebut kemudian dalam bahasa Jawa dipelintir menjadi kata "ndeso"untuk menyebut orang-orang atau penduduk yang berada di "udik" atau "pedalaman"atau yang punya sifat "kampong(an)" [5]. Dalam kamus Besar Bahasa Indonesia kata"desa" diartikan sebagai kesatuan wilayah yang dihuni oleh sejumlah keluarga yang mempunyai sistem pemerintahan sendiri [6].

Keberadaan desa sebagai satu kesatuan masyarakat hukum memberi pemahaman yang mendalam bahwa institusi desa bukan hanya sebagai entitas administratif belaka tetapi juga entitas hukum yang harus dihargai,diistimewakan, dilindungi dalam struktur pemerintahan di Indonesia. Hal ini yang kemudian tertuang dalam UUD 1945 pasal 18 B ayat (2) yang menyatakan:

\footnotetext{
"Negara mengakui dan menghormati kesatuan-kesatuan masyarakat hukum adat beserta hakhak tradisionalnya sepanjang masih hidup dan sesuai dengan perkembangan masyarakat dan prinsip Negara Kesatuan Republik Indonesia, yang diatur dengan undang-undang".
}

Dari pemahaman pasal 18 B ayat (2) UUD 1945, bahwa desa diartikan bukan saja sebagai kesatuan masyarakat hukum adat, tetapi juga sebagai hirarki pemerintahan yang terendah dalam NKRI [7].

Istilah pemerintahan dan pemerintah dalam masyarakat secara umum diartikan sama, dimana kedua kata tersebut diucapkan bergantian (pemerintah atau pemerintahan). Sebutan kedua kata atau istilah tersebut menunjuk pada penguasa atau pejabat. Mulai dari Presiden hingga Kepala Desa, artinya semua orang yang memegang jabatan disebutlah pemerintah atau pemerintahan, tetapi orang yang bekerja di dalam lingkungan pemerintah atau pemerintahan disebut orang pemerintahan [8].

Menurut Efendi Berutu [9], pemerintahan mempunyai pengertian dalam arti luas dan sempit. Pemerintahan dalam arti luas berarti seluruh fungsi negara seperti legislatif,eksekutif dan yudikatif. Sedangkan pemerintahan dalam arti sempit meliputi eksekutif saja. Dalam literatur yang lain Montesquie mengartikan pemerintahan dalam arti luas meliputi: pembentukan undang-undang (la-puissance legislative); pelaksanaan (lapuissance executive); dan peradilan (la-puissance de juger). Ajaran Montesquieu ini dikenal dengan ajaran tentang pembagian kekuasaan negara yang popular disebut dengan "trias politika" [10].

Seiring dengan bergulirnya reformasi 1998, yang mana salah satu tuntutannya adalah diberlakukannya otonomi daerah secara luas, maka telah terjadi pergeseran dalam dinamika pemerintahan di Indonesia khususnya mengenai desa.Jika masa sebelum reformasi bersifat sentralistik maka setelah reformasi menjadi desentralisasi.Bergulirnya otonomi daerah tersebut yang artinya adalah terdapatnya keleluasaan pemerintah daerah (dicretionary power) untuk menyelenggarakan pemerintahan sendiri atas dasar prakarsa, kreativitas dan peran aktif masyarakat dalam mengembangkan daerahnya. Namun kebebasan dan kemandirian dalam otonomi daerah bukan berarti kemerdekaan lepas dari Negara Kesatuan Republik Indonesia (NKRI) melainkan kebebasan dan kemandirian yang tetap dalam ikatan negara kesatuan.

Dengan perubahan tata hukum yang mengatur tentang desa dimana awalnya masuk pada undang-undang tentang pemerintahan daerah baik dalam UU No.22 Tahun 1999 maupun UU No.32 Tahun 2004 maka sejak tahun 2014 desa telah memiliki sendiri undang- 
undangnya yaitu UU No.6 Tahun 2014 tentang desa.

Dalam undang-undang ini pemerintahan desa diberi kewenangan yang lebih besar dalam mengatur dan mengelola sumber daya alam dan sumber daya manusia dengan diberikan juga suntikan dana dari pemerintah pusat yang besarnya antara 750 juta-1 M setiap desa setiap tahunnya. Tujuan dari hal tersebut adalah agar ketimpangan antara desa dan kota dapat diminimalisir sehingga urbanisasi penduduk dari desa ke kota dapat ditekan seminimal mungkin.

Namun dalam perkembangannya karena posisi desa yang jauh dari pusat perkotaan telah menjadi sasaran strategis bagi penyebaran paham radikal terorisme. Selain sebagai tempat penyebaran, desa juga digunakan sebagai tempat persembunyian atau markas para penganut paham radikal terorisme karena jauhnya jangkauan dari aparat keamanan.

Tentunya kita masih ingat dengan kasus tertangkapnya Dr. Azhari di Kota Batu Malang yang juga menjadikan desa atau vila sebagai tempat persembunyian. Atau juga tertangkapnya Amrozi dkk di kabupaten Lamongan yang juga menjadikan desa sebagai awal mereka merancang pemboman Bali. Kemudian juga peristiwa penusukan Menkopolhukam Wiranto pada tahun 2019 ada di Kabupaten Pandeglang dimana aktor nya juga berasal dari desa.

Maka pemberian insentif dana pembangunan desa hanya akan membangun fisik desa namun tidak membangun psikis masyarakat desa terutama terkait penangkalan paham radikal terorisme. Dibutuhkan pendekatan tidak hanya sekedar stimulan dana namun juga pembangunan mental dan pemahaman agama yang lebih agar masyarakat desa lebih mawas terhadap lingkungan sekitarnya khususnya terkait dijadikannya desa sebagai sarang para terorisme.

\section{PENUTUP}

\section{Kesimpulan}

Berdasarkan uraian pembahasan dan latar belakang tersebut diatas, maka dapat ditarik benang merah sebagai kesimpulan sebagai berikut:

1. bahwa keberadaan paham radikal terorisme berawal dari munculnya paham intoleran diantara umat manusia akibat terbatasnya pemahaman agama yang dimiliki sehingga memunculkan paham cauvinisme diantara para pemeluk agama

2. menyebarnya paham radikal terorisme di desa selain akibat karena pengaruh ekonomi namun juga karena pengaruh pendidikan dimana akses pendidikan masyarakat desa ke kota sangat jauh. Sehingga desa dijadikan sarang oleh para terorisme.

\section{Saran}

1. memperkuat pemahaman dan pengimplementasian nilai-nilai pancasila dalam setiap sendi kehidupan manusia khususnya di Indonesia melalui tidak hanya pelajaran namun juga contoh tindakan oleh para pemimpin;

2. aparat pemerintahan desa harus lebih sering melakukan kontrol terhadap warganya terutama yang rumahnya jauh atau terpisah dari rumah-rumah warga desa yang lainnya.

\section{DAFTAR PUSTAKA}

[1] https://radarlampung,co.id/2019/08/21/Lampung-Peringkat-4- Rentan-Radikalisme/21 Agustus 2019.

[2] https://amp.kompas.com/nasional/read/2019/10/21/18343051/polisi-tangkap-3-terduga-teroris-dilampung.

[3] Syarifuddin, Ateng. 2010. Republik Desa. Alumni:Bandung. 
[4] Titik Triwulan Tutik. 2006. Pokok-pokok Hukum Tata Negara Prestasi. Pustaka:Jakarta.

[5] Moh. Fadli, Jazim Hamidi dan Mustofa Lutfi. 2011. Pembentukan Peraturan Desa Partisipatif. Brawijaya Press:Malang.

[6] Tim Penyusun kamus Pusat Pembianaan dan Pengembangan Bahasa. 1995. Kamus Besar Bahasa Indonesia Cet. VII. Balai Pustaka:Jakarta.

[7] Khairuddin Tahmid. 2011. Dekonstruksi Politik Hukum Otonomi Desa Dalam Peraturan Perundangundangan Di Indonesia (Yogyakarta:ringkasan disertasi progam doktor UII), hlm.3.

[8] Sukaryono, Didik. 2010. Pembaharuan Hukum Pemerintah Desa. Malang:Setara Press.

[9] Sinamo,Nomensen. 2010. Hukum Pemerintahan Daerah di Indonesia. Pustaka Mandiri:Jakarta.

[10] Sadjijiono. 2008. Memahami Beberapa Bab Pokok Hukum Administrasi. Laksbang Pressindo: Yogyakarta. 